\title{
A integração das artes e a pós-modernidade
}

VERA BONNEMASOU 


\section{Resumo}

O trabalho desenvolve uma relação entre os períodos da modernidade, modernismo e pós-modernidade e o modo como as artes se apresentam, inicialmente isoladas e, pouco a pouco, integrando-se de várias maneiras. Chega-se, deste modo, à pós-modernidade na qual à interação entre autor, obra e receptor vem se acrescentar uma integração entre os meios, consistido no conceito de hipertexto.

\section{Palavras-chave}

integração, periodização, pós-modernidade, interação, mídia

\section{Abstract}

This article develops the relationship between the periods of modernity, modernism, and post-modernity and the way the arts present themselves, initially in an isolate mode and then gradually integrating themselves in different manners. In this way, one arrives at post-modernism where integration between the media, consisting of the hypertext context, is being added to the interaction between author, oeuvre and receptor.

\section{Key words}

integration, periodization, pós-modernity, interction, midia 
niciaremos esta reflexão sobre a integração da artes, pela idade moderna, que vamos considerar como estendendo-se do Renascimento até o século XIX, quando as artes visuais são definidas nas categorias: desenho, pintura, gravura, escultura e arquitetura. Enquanto na música se fixou o sistema tonal, que irá predominar até o início de nosso século, nas artes visuais há a hegemonia da perspectiva monocular.

Desejou-se, neste período, que as artes pudessem ser reversíveis, resumindo-se a um só princípio, ideal caro a Wagner (a obra de arte total), assim como a Goethe. Deste modo, a um som corresponderia uma cor e até um gesto ou uma letra, na procura do que seria uma interface (avant la lettre) entre as linguagens. A finalidade desta correspondência era o intercurso dos sentidos, por meio da sinestesia, proporcionando um aumento da percepção. É este também o significado de se considerar a compreensão da forma como a essência da compreensão ela mesma, pois, segundo Pignatari, ${ }^{1}$ é na tradução formal, estabelecida entre as várias linguagens, que se atinge o verdadeiro conhecimento. Parece residir aí o sonho da correspondência entre as artes, logo abandonado por se ter compreendido que cada arte possui o seu próprio meio de expressão e que só respeitando-se a sua peculiaridade esta pode significar.

A partir do modernismo, que se pode compreender como uma fase de demolição dos valores modernos ocorrida aproximadamente até a década de 60 do século XX (Santaella, 2000, p.85), acontece a hibridização, ou seja, a mistura de meios diferentes, tan-

1. A arte é o oriente dos signos; quem não compreende o mundo icônico e indicial, nāo compreende corretamente o mundo verbal, não compreende o Oriente, não ccompreende poesia e arte. (Ct. Pignatari, 1987, p.17). 
to no interior de uma mesma arte - como, por exemplo, a colagem na pintura -, como na junção entre diferentes artes, pretendendo-se, deste modo, atingir o fruidor com níveis mais altos de singularidade ou estranhamento.

Valeria a pena analisar, além do que se ganha, o que se perde quando a arte abandona a pureza de uma técnica, a qualidade compreendida como o virtuosismo adquirido no manejo dos instrumentos, necessário para se atingir a perfeição. Assim, por exemplo, o uso do pincel, tão valorizado na arte oriental, em que se observam os índices deixados pelo artista no decorrer da obra e que nos revelam a essência do que é representado. Nesta concepção de arte, muito pouco valor é dado ao novo, visto que o que se quer transmitir não reside na originalidade, mas na habilidade da interpretação. ${ }^{2}$

Vemos, portanto, que, no hibridismo, iniciado com o modernismo, essa habilidade vai sendo substituída pela originalidade, a técnica é substituída pela imaginação e o virtuosismo pela improvisação. Formular assim a questão, entretanto, é ignorar que outros virtuosismos surgirão: perde-se, assim, o virtuosismo da linguagem, mas não o do meio que a embute.

Portanto, entre o modernismo e a pós-modernidade, visualizam-se os dois aspectos em que a integração pode ser pensada: a hibridização entre as várias modalidades artísticas, que ocorrem dominantemente no modernismo entre as artes tradicionais, e a que acontece entre estas e os multi-meios, mais própria da pósmodernidade.

Do ponto de vista das novas tecnologias, são infinitas as possibilidades de interferência entre as linguagens tanto no nível sintático como no semântico do signo. Como exemplo do primeiro caso, temos o poema-montagem de Julio Plaza, "Brasil país do futuroboros" (fig.1), em que há a fusão da conhecida frase proferida por Stefan Zweig - que grudou como um chiclete na estima do bra-

2. Talvez o ponto de inflexão, entre a habilidade como é considerada na arte oriental e a procurada pela arte acadêmica ocidental, é que a primeira nunca perde de vista o receptor, como nos indicam as chaves a da estética taoista: - Ressonância, Reticência e sugestão, Ritmo vital e Vazio, - recuperadas entre nós pelas vanguardas. (cf. Plaza, op.cit., p.26). 


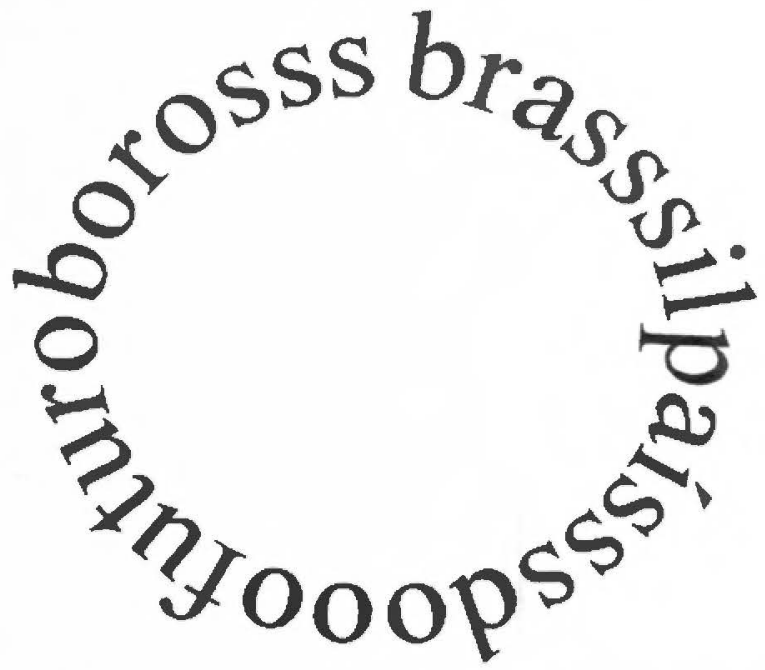

Fig. 1. Brasil país do futuroboros, Julio Plaza, 1990.

sileiro (Plaza, apud Sylvio Back, 1998: 214) e a forma do uroboros. E, do segundo caso, "It's $P$ " de Lilian Schwartz (fig.2), a combinação dos rostos da Mona Lisa e de Leonardo da Vinci. Se, no primei-

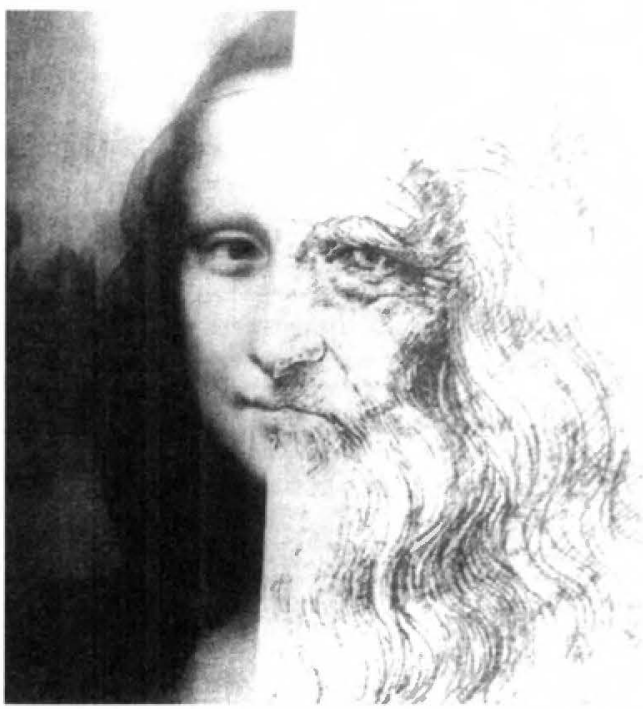

Fig. 2. "It's I". Lilian Schwartz. 1984. 
ro caso, temos uma montagem na frase "Brasil pais do fut + uroboros" no segundo, trata-se de uma bricolagem, visto que os fragmentos utilizados denotam a sua procedência. Finalmente, fazendo-se a junção de duas artes, podemos citar o videopoema de Plaza, uma montagem da fita de Moebius e do texto"o arco íris no ar curvo" que dá o título à obra, à qual foi incorporada a música minimalista de Terry Riley, "The rainbow in the curved air", tornando-a, deste modo, intertextual (fig. 3$)^{3}$

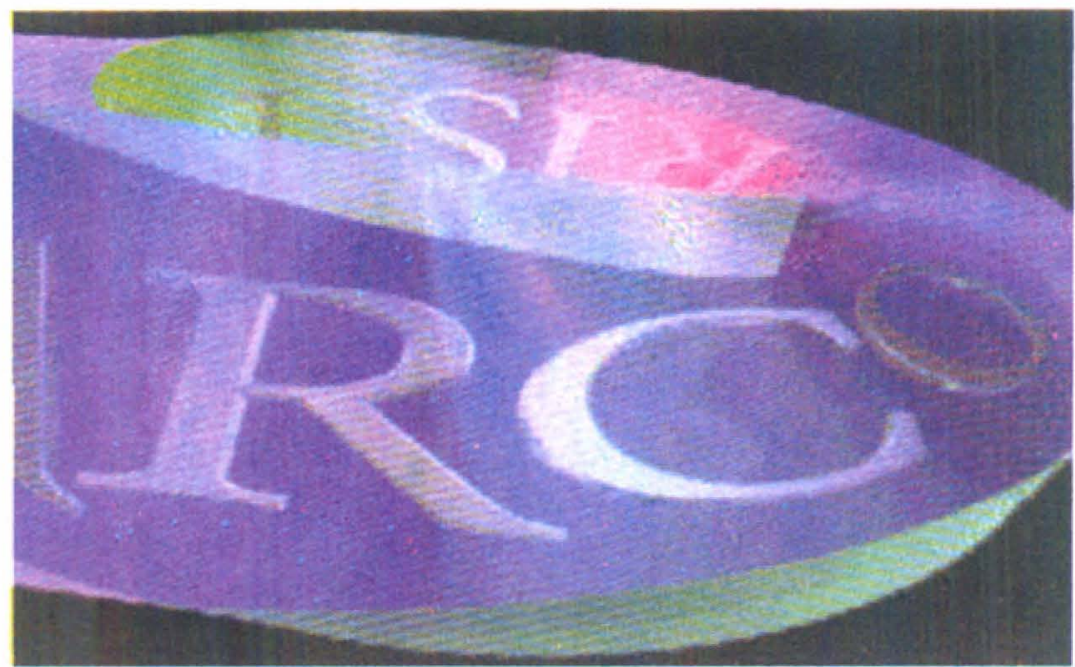

Fig. 3. Frame do videopoema $O$ arco íris no ar curvo. Julio Plaza,.

1994

Note-se que dois tipos de integração são possíveis, a que ocorre pela montagem, decorrente de uma similaridade entre os meios: de A e $\mathrm{B}$ resulta $\mathrm{C}$; e a que é decorrente de uma união onde a similaridade não existe e precisa ser criada por meio da interface, um dispositivo físico ou lógico que faz a conexão entre dois equipamentos que não podem se conectar diretamente. Deste modo é criado unn isomorfismo artificial reunindo dois elementos de forma sinergética.

3. Todos os exemplos in Plaza e Tavares, pp:214, 219. 


\section{Os vários sentidos da obra e a pós-modernidade}

O termo "neo-barroco"4, usado como um sinônimo de pósmoderno, sugere-nos o de abertura da forma a vários significados, dentro do conceito de obra aberta formulado por Umberto Eco: "uma mensagem fundamentalmente ambígua, uma pluralidade de significados em um só significante" (Plaza, apud Eco, op. cit. $)^{5}$.

Omar Calabrese, autor desta "etiqueta" feita para substituir o termo pós-moderno, assim explica este novo slogan: "A minha tese geral é que muitos fenômenos de cultura do nosso tempo são marcas de uma 'forma' interna específica que pode trazer à mente o barroco". O autor salienta que pretende apenas sustentar que características formais do barroco podem ser reconhecidas a partir da década de 60 , tendo-se manifestado vigorosamente na arquitetura. $\mathrm{O}$ autor assim se expressa:

...e qual será ele, o gosto predominante deste nosso tempo, aparentemente tão confuso, fragmentado, indecifrável? Creio tê-lo encontrado, e também proponho para ele um nome, $o$ de "neo-barroco". Mas preciso desde já que a etiqueta não significa que tenhamos retornado ao barroco, nem que o que eu defino como "neo-barroco"seja a totalidade das manifestações estéticas desta sociedade, ou o seu âmbito dominante, ou o mais positivo.(...) No que consiste o "neobarroco" está quase dito. Encontra-se na procura de formas - e na sua valorização -, em que assistimos à perda da integridade, da globalidade, da sistematização ordenada em

4. Termo cunhado por Omar Calabrese em sua obra "A idade neo-barroca". ...a saber, que todo o fenômeno analisado é sempre, enquanto analisado, um fenômeno construído pelo analista e, portanto, transferivel para lá da própria colocação espacial e temporal, p.33.

5. Conforme Julio Plaza (2000, p. 23), a abertura da obra de arte à recepção, relacionada necessariamente às três fases produtivas da arte: a obra artesanal (imagens de primeira geração), industrial (imagens de segunda geração) e eletroeletrônica (imagens de terceira geração), detona vários graus para a interpretação. A Obra Aberta se identifica com a "abertura de primeiro grau" pois remete à polissemia, à ambigüidade, à multiplicidade de leituras e à riqueza de sentido." 
troca da instabilidade, da polidimensionalidade, da mutabilidade (Calabrese, 1988, pp.10-11).

Assim, a capacidade de perceber semelhanças e diferenças entre fenômenos de aparência distante, como o barroco e a arte atual, é "Uma forma. Um princípio abstrato de organização dos fenômenos. Que preside ao seu sistema interno de relações" (idem).

Embora esta analogia, estabelecida entre duas épocas e duas artes tão distintas, não deixe de ser elucidativa, adotamos preferivelmente o nome de pós-modernidade para a etapa contemporânea, segundo a periodização triádica desenvolvida por Santaella:

De acordo com tal diagrama, e com todos os riscos de uma estratificação simplificadora, a modernidade ou era moderna não começa no iluminismo, como querem alguns filósofos, nem com Baudelaire, como querem os literatos, mas recua para a crise do feudalismo e os primórdios do modo de produção capitalista. Seus marcos temporais mais ou menos ziguezagueantes estão no Renascimento nas artes, quando se dá a codificação dos sistemas artísticos nas cinco belas artes, a invençâo da perspectiva na pintura e a aurora do sistema tonal na música.(...) As "Flores do mal" foram o canto do cisne da era moderna que se iniciara com o Renascimento, e puseram o território da arte em prontidão para os abalos sísmicos e turbulências estáticas que iriam surgir com aquilo que foi chamado de "modernismo" nas artes, literatura e música.(...) A partir dos anos 60 , contudo, algo diferencial começou a emergir de um feixe de fatores dominados pela explosão da cultura de massas e sob o impacto da Revolução Eletrônica, no seio do capitalismo de consumo.(...) O diagrama que estou aqui propondo, e que toma como ponto de partida o recuo da modernidade para o Renascimento, não estabelece uma oposição ou ruptura entre o modernismo e a pós-modernidade. Ao contrário, o modernismo correspondeu ao ponto de inflexão, precipitação da crise da razão, desconstrução dos valores modernos, en- 
quanto a pós-modernidade deve corresponder à aurora de uma nova era... (Santaella, 1980, pp.126-128-129).

Voltando à nossa tese inicial, a da integração das artes em sua evolução, e partindo da linguagem para os meios, característica de nossa época, ${ }^{6}$ chegamos, assim, ao terceiro tópico do artigo já citado, de Julio Plaza, "Arte e interatividade: a abertura de terceiro grau", remetendo ao conceito mcluhiano "o meio é a mensagem".

Desse artigo, podemos inferir que a intertextualidade, própria da abertura de primeiro grau, ressurge com a noção de hipertexto, já agora na abertura de terceiro grau. Ted Nelson, considerado o inventor deste termo, conceitua-o como "conjunto de escritas associadas, não sequienciais, com conexões possíveis de seguir e oportunidades de leitura em diferentes direções" (Plaza, 2000, p. 35).

Chegamos, assim, à hipermídia, própria da tecnologia computacional, na qual há uma transferência do poder do autor para o leitor. Sem entrar na questão da autoria e seus desdobramentos, vemos que a hipermídia é a que melhor define a pós-modernidade, a qual, com Lucia Santaella, espera-se que seja a aurora de um novo homem e, especialmente, de uma nova arte.

É este novo ser criador, denominado "designer da informação", por E. G. Boccara, preferivelmente a "artista", que aparece como conseqüência final do hibridismo. Este terminou por se constituir fundamentalmente em informação. Segundo este autor:

O que em analogia tecnológica corresponde à fragmentação perceptiva humana, segmentada e especializada, temos correspondência através da mídia (forma plural para vários meios) e o que vemos neste momento é a convergência através do computador para uma única e totalizante SuperMidia, talvez a reconhecida e mítica obsessão humana da totalidade perceptiva e expressiva portanto também comu-

6. Na arte de tipo artesanal, a qualidade é compreendida como habilidade manual, e a obra está centrada no produto. Com o advento do uso de aparelhos desenvolvido durante o modernismo, vai ocorrendo uma ruptura deste sentido primitivo, cujo enfoque passa do produto à produçāo. 
nicativa. Isto então recoloca a questão da superação de fronteiras das especializações e a busca de uma síntese renovadora e restauradora das rupturas perceptivas ou expressivas, que configuram historicamente as linguagens conhecidas, que por serem linguagens carregam o estigma redutor de suas naturezas codificadoras. (Boccara, 2001, p. 87)

Com esta nova tecnologia, não se busca mais o "bom" e o "ruim", porém a opção - a arte participativa, a qual substitui a contemplação pela sensação de comunicação (Plaza apud Pino, op. cit.: 26). Assim, a arte passa de produto à produção. Não é mais"o resultado de uma continuidade espontânea do movimento da mão, mas uma vontade de forma..." o que determina o que é arte. (Plaza apud Moles, op. cit.:30).

\section{Bibliografia}

ARNHEIM, Rudolf. 1980. Hacia una psicologia del arte. Madrid: Alianza Editorial.

BOCCARA, Ernesto Giovanni.2002. "As questões das Artes, do Design e a convergência das mídias através da tecnologia computacional: o surgimento de linguagens híbridas no contexto da comunicação social contemporânea". Cadernos da Pós-Graduação. Instituto de artes/Unicamp. Ano 5 - vol. 5 - nº 2 - 200.

CALABRESE, Omar.1987. A Idade Neoneo-barroca. São Paulo: Martins Fontes.

PEIRCE, Charles Sanders.1995. Semiótica. São Paulo: Perspectiva.

PIGNATARI, DecioDécio. 1987. Semiótica e literatura. São Paulo: Cultrix., 1987.

PLAZA, Julio e TAVARES, Mônica. 1998. Processos criativos com os meios eletrônicos: poéticas digitais. São Paulo: Hucitec.

PLAZA, Julio. 2000. "Arte e Interatividade: Autor-ObraReccpçãoRecepção". Cadernos da Pós-Graduação. Instituto de Artes/Unicamp. Ano 4 - vol. 4 - $\mathrm{n}^{\circ} 1$.

SANTAELLA, Lucia. 2000. Cultura das mídias. 2.ed. São Paulo: Experimento. 